IRA-International Journal of Management \& Social Sciences

ISSN 2455-2267; Vol.05, Issue 01 (2016)

Pg. no. 152-158

Institute of Research Advances

http://research-advances.org/index.php/RAJMSS

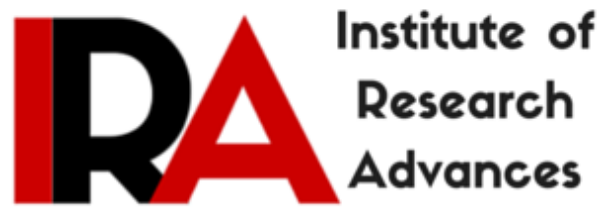

\title{
M-Commerce: A Necessity for Future India
}

\author{
Dr. Priyanka Khurana \\ Assistant Professor \\ Department of Accountancy \& Business Statistics \\ Kanoria PG Girls College, Jaipur, India.
}

Type of Review: Peer Reviewed.

DOI: http://dx.doi.org/10.21013/jmss.v5.n1.p15

\section{How to cite this paper:}

Khurana, P. (2016). M-Commerce: A Necessity for Future India. IRA-International Journal of Management \& Social Sciences (ISSN 2455-2267), 5(1), 152-157. doi:http://dx.doi.org/10.21013/jmss.v5.n1.p15

(C) Institute of Research Advances

(c) ) EY-NC

This work is licensed under a Creative Commons Attribution-Non Commercial 4.0 International License subject to proper citation to the publication source of the work.

Disclaimer: The scholarly papers as reviewed and published by the Institute of Research Advances (IRA) are the views and opinions of their respective authors and are not the views or opinions of the IRA. The IRA disclaims of any harm or loss caused due to the published content to any party. 


\begin{abstract}
Innovation is the change that unlocks new value. With the increased use of mobile internet and innovative smartphones, the business has transformed from direct selling to mobile selling in India. People now-aday have become 'mobify'. Use of tablets, smartphones and i-pad has become common for a common man. The next generation e-commerce, m-commerce enables buying and selling of goods and services through wireless handheld devices which not only provides convenience but also speedifies the quality and quantity of transactions. Mutual Funds are the most preferred financial investment in today's scenario. M-commerce will help the Mutual Fund Industry to reach greater heights with advancements in technology. The purpose of this study is to evaluate the current status of mobile commerce in India with special reference to Mutual Funds and to establish m-commerce as a necessity for Future India. The researcher has used analytical approach to undertake this study. A questionnaire was prepared and data was collected regarding the financial preference of investors and also the mobile internet users in India. The study concluded that technology based smarter ways of doing business will be the natural favourites for doing business in Future India. India's growth through financial sector and m-commerce will contribute towards shaping India for a better tomorrow. And by 2020, m-commerce will be the most preferred place for marketers, content creators and advertisers to reach out target audience.
\end{abstract}

\title{
Introduction
}

Innovation is the change that unlocks new value. With the increased use of mobile internet and innovative smartphones, the business has transformed from direct selling to mobile selling in India. People now-aday have become 'mobify'. Use of tablets, smartphones and i-pad has become common for a common man. According to a report, India contributed to 7 per cent of the global app downloads, ranking fourth behind Indonesia, China and the US. And, the mobile app download is estimated to grow six-fold by the end of this year to 9 billion apps. The country has been the fastest growing mobile app market in both 2014 and 2013. Investment in mutual funds has grown very fast and has spread to almost every remotest part of the country. Due to the growth of Mutual Fund Industry, they are preferred by investors as an investment. Mutual Funds are a special type of investment vehicle that provide variety of schemes to all type of investors along with the benefit of professional management, diversification and balanced risk as compared to other investment avenues. Now an investor can start his investments from `50. Mobile commerce now-a-days is a smarter way of communicating product information to the customers. It is a smarter way ahead for mapping India's growth. Companies have started using Facebook and WatsApp for marketing and selling purposes. With over 431 million internet capable devices in India, internet access is easy for customers and investors. M- commerce market in India will grow at a CAGR of 71.06 $\%$ till 2016. The smartphone users today are 44 million in number which is growing at $150 \%$ year over year.

\section{M-commerce: Need of the Hour}

M- Commerce means exchanging goods and services over the internet by the use of mobile smart phones. With new technologies, mobile phones have transformed direct selling to online selling and now to mobile selling. The next generation e-commerce viz. m-commerce enables buying and selling of goods and services through wireless handheld devices which not only provides convenience but also speedifies the quality and quantity of transactions. M-commerce services comprises of M-Banking, MEntertainment, M-Shopping, M-Marketing and M-Information services. The trade is just a minute's job. You have to download the app and almost everything is available easily at your fingertips. Mobile apps are now considered as a significant new avenue to target consumers. This is because of increased use of 
mobile phones. India has more than 300 million internet users and ranks third in internet penetration at $19.2 \%$, after China and US. This figure is expected to touch 503 million by 2017 . The number of internet users in urban India is 197 million while in rural belt it is increasing at 58\% year on year growth. Also, India has the fastest growing mobile subscriber base in the world with 950 million mobile users. This is around $81 \%$ of India's population. This provides great opportunity for m-commerce in the country. The number of smartphone owners using mobile apps of e-commerce companies has gone up from 1,680 (21\%) in May 2014 to 4,320 (54\%) in May 2015, based on real-time mobile usage data across 8,000 handsets in the country. With number of smartphone users increasing in the country and e-commerce firms focussing on m-commerce, India has registered global app usage of 131 per cent growth. Around 10 billion apps will be downloaded in India in 2016, more than six times the number of apps downloaded in 2012 (1.56 billion) at a cumulative annual growth rate (CAGR) of approximately 75 per cent. With several such avenues opening up, advertisers, content creators and marketers are expected to continue working towards new and more innovative ways to reach out to their target audience. And, mobile commerce is the smarter way out for this.

\section{Objectives of the study}

The objectives of the study are as follows:

- To understand the need of m-commerce as the necessity for future India

- To study the concept of mobile commerce

- To establish m-commerce as an innovative next generation e-commerce tool

- To identify ways by which m-commerce can increase number of investors in Mutual Fund Industry

\section{Review of Literature}

Gupta \& Vyas (2014) says that $\mathrm{m}$ commerce is at emerging level in India and it is complex to adapt. People have started using mobile not only to make phone call but use it for web access, chatting, surfing and also shopping. He has discussed about how m-commerce is developing in India and identified clear context and assistant mechanism.

Mirzae, Asadollahi, \& Jahanshahi (2014) has proposed a study about brief description about mobile wireless technologies, relationship between e commerce and $\mathrm{m}$ commerce, help business to define what they can derive from $\mathrm{m}$ commerce, fundamentals of e commerce and $\mathrm{m}$ commerce, categories of mobile commerce applications.

Batra \& Juneja (2013) has extended their research on mobile commerce in India. It lists the issues faced by M Commerce Industry. According to him the growth drivers of m-commerce are Instant Connectivity, Personalization factor, mobility Factor, Immediacy, Localization etc.

Tandon, Mandal, \& Saha (2013) has explored and presented the possible issues in mobile e commerce. He had tried to bring out the potential benefits and challenges associated with the technology.

\section{Research Methodology}

The researcher has used analytical approach to carry out this research. A questionnaire was prepared to collect primary data from mutual fund investors and data was collected regarding the financial preference of investors and also the mobile internet users in India. The secondary data is basically dependent on sources such as internet journals, books, magazines, newspapers and various websites. 


\section{Mutual Funds: A Must for Future India}

Mutual Fund Industry is growing at a faster pace. Mutual Funds are the most appropriate and preferred investment avenue for individual investors as it offers an opportunity to invest in a diversified, professionally managed basket of securities at a relatively low cost. A fund is "mutual" as all of its returns, minus its expenses, are shared by the investors of the fund. To state simply, a mutual fund collects the savings from small investors, invest them in Government and other corporate securities and earn income through interest and dividends, besides capital gain. It works on the principle of 'small drop of water makes a big ocean'. The factors which can be largely attributed to impressive growth in the Indian Mutual fund industry are increased household savings, advantageous tax policies, and introduction of several new products, investor education and the role of distributors. Indian growth is essentially expected at a higher pace when its financial market is growing. This is possible with more and more Mutual Fund investors adding to the industry. Another innovation in Mutual Fund Industry is 'Make in India Mutual Funds'. These funds invest money in manufacturing, auto, pharma sectors besides others. They support the Make in India campaign launched by Honorable Prime Minister of India, Narendra Modi. Mutual Fund Industry is undoubtedly a must for future growth of the economy as they are the most preferred investment avenue for variety of small as well as big investors.

\section{M-Commerce \& Mutual Funds: The Next Generation e-commerce}

The revolution in the development of communication technology has become so advanced and that also helped to link the issuers of financial instruments with the investors in the global financial market without any difficulty. All these developments lead to economic growth and the dynamics of economic growth provide various opportunities not only in the Indian market but also in the global market for investors to invest their savings in different attractive avenues of investments with various features matching with their financial goals.

Indian Mutual Funds have emerged as strong financial intermediaries and they play a significant role in bringing stability into the financial system and efficiency in resource allocation. These are suitable for all types of investors from risk adverse to risk bearer. Mutual Funds have many options of return, risk free return, constant return, market associated return, etc. They are suitable to all age of investors, businessmen, salary person, etc. Investors need not be expert in equity market; Mutual Funds can satisfy their need. Fund managers are expert in this area and invest fund in well diversified portfolio. High return with low risk is possible in Mutual Fund. In today's world, investors are showing more trust in Mutual Fund than any other financial product. There is no need of a financial consultant, if you have good knowledge of Mutual Funds and their type to invest. Mutual Fund is subject to market risk, despite of that it have low risk than stock market.

Mobile commerce is the next generation e-commerce way out to reach the audience. As it comprises of mobile marketing, mobile banking, mobile entertainment, mobile shopping and mobile information services, it is the easier, convenient and effective innovation to use as e-commerce tool. To carry out the research work and to determine the effectiveness of mobile phones to reach out the Indian users, a questionnaire was prepared and data was collected from a sample of 100 investors including businessman, professionals and retired individuals. The data collected was then analyzed and following are some of the results: 


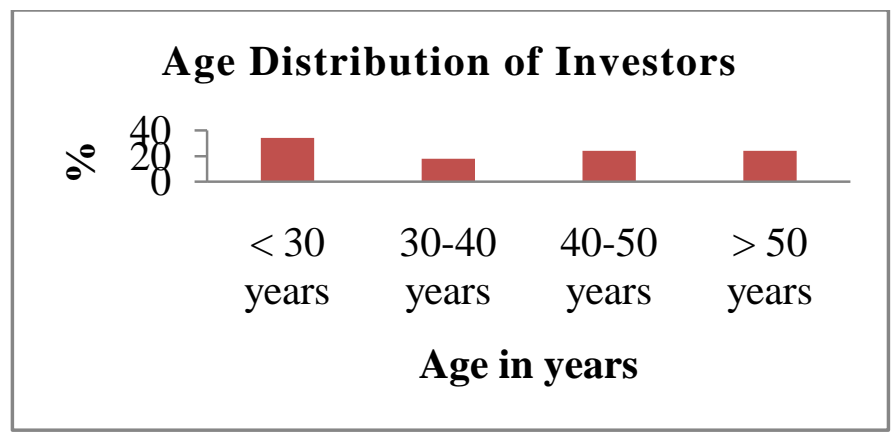

\section{Age Distribution of Investors}

The above figure shows the age wise analysis of the respondents. It shows that almost $34 \%$ of the investors of Mutual Funds belong to younger age group i.e below the age of 30 years.

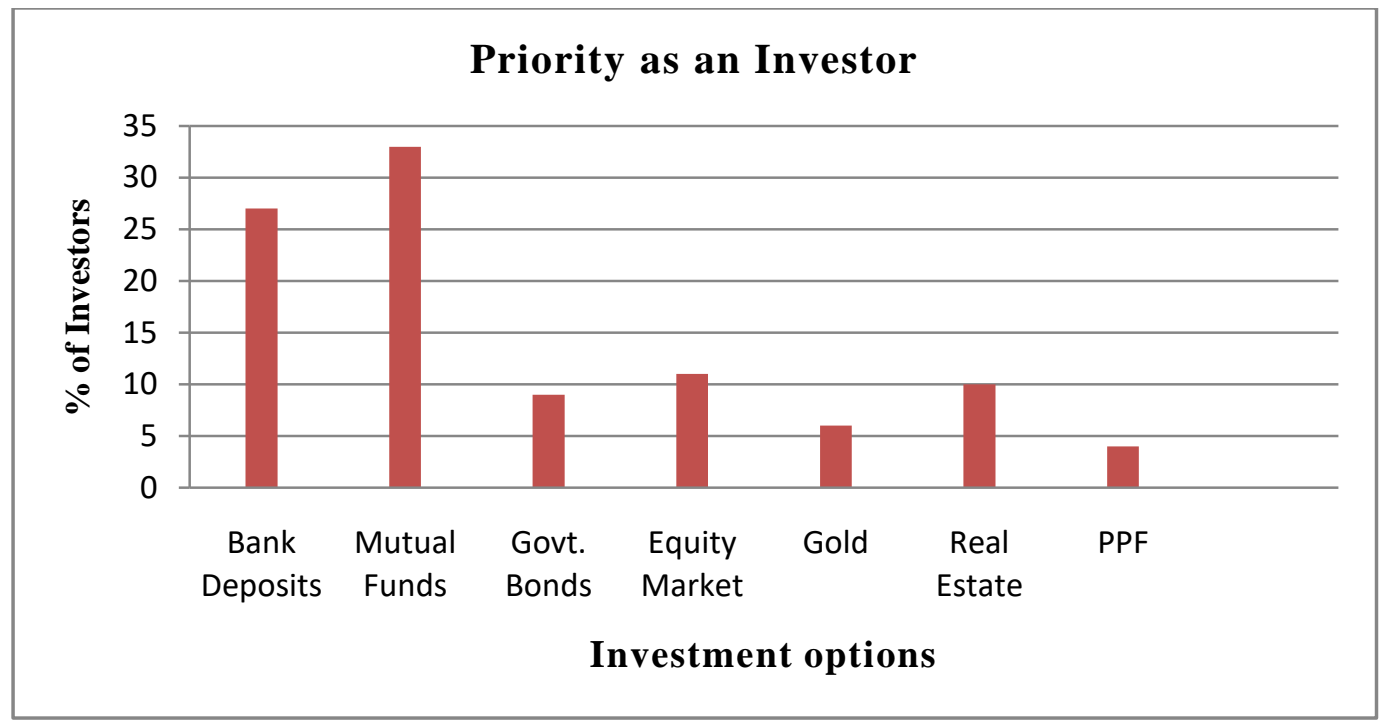

\section{Priority as an Investor}

The above data collected for the priority of different investment avenues as an investor revealed that around $60 \%$ of the respondents preferred Mutual Funds along with Bank Deposits in today's scenario. This provides a wide scope for e-banking and e-commerce.

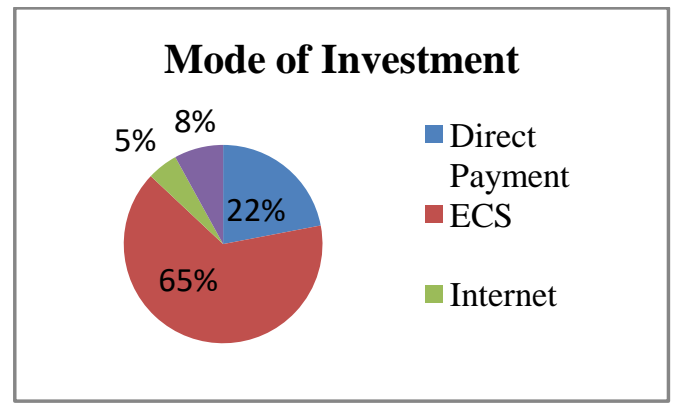




\section{Mode of Investment provided to Investors}

On analyzing, the preferred mode of investment, it has been evaluated that $70 \%$ of the investors prefer ECS and Internet.

\section{MOBILE INTERNET USERS IN INDIA 2013-17 (E)}

(in million)

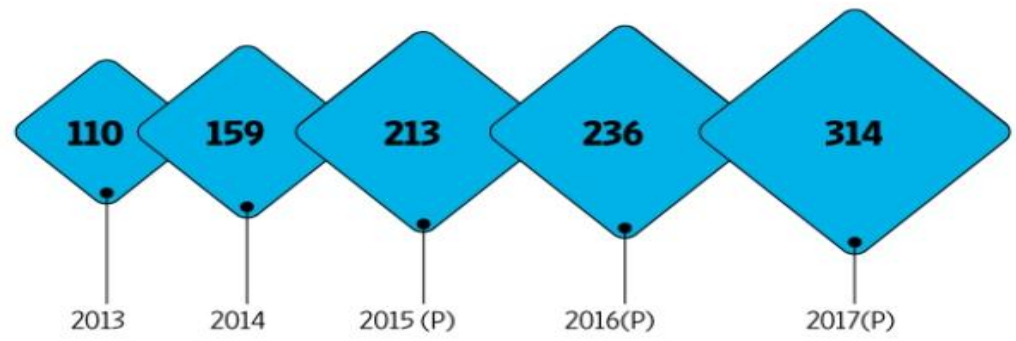

Source: lamai-IMRB Mobile Internet in India 2014 report; KPMG-Ficci M\&E industry report 2015

\section{Mobile $=41 \%$ of India E-Commerce... \\ $=$ More Mobilized vs. Most Other Countries*}

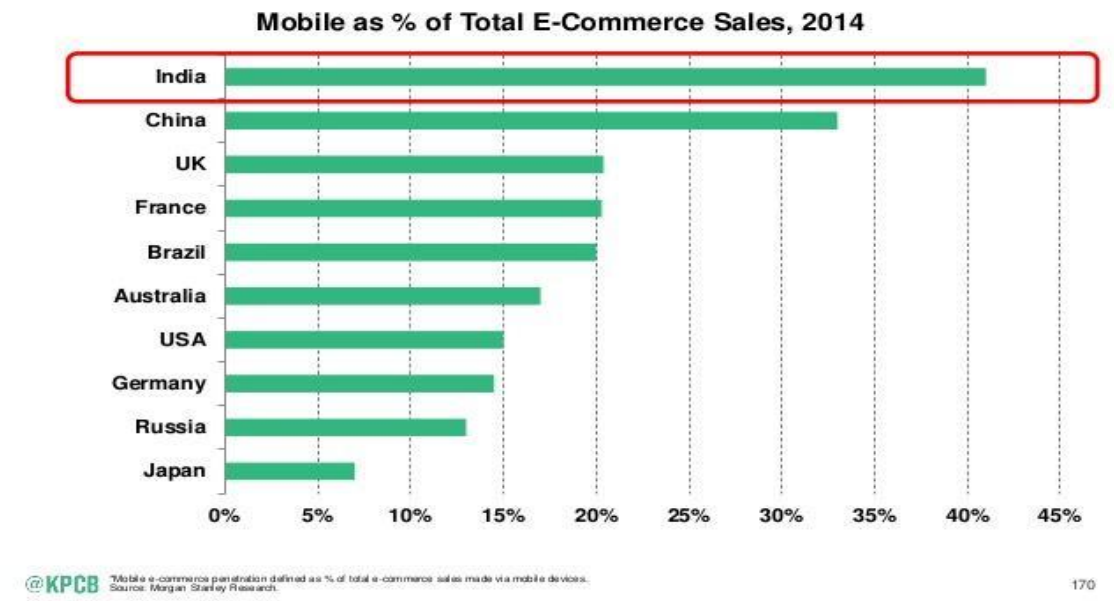

According to the above data, $41 \%$ of the e-commerce sales come through mobile phones. With the mobile internet users' increasing day by day, the m-commerce is expected to grow to around $70 \%$ by 2020 . With more than 930 million mobile customers, and with the domestic Smartphone market growing at 84 per cent in the second quarter of 2014, m-commerce is expected to grow rapidly. Major reason for the increase in mobile commerce is the penetration of smartphone into the rural markets, 45 per cent of the online users in India access internet only through their mobile phones. Yearly m-commerce sales are forecasted to increase fourfold billion in the next few years. Businesses are beginning to realize that $\mathrm{m}$ commerce is the key to enhance their brand, boost sales, and keep up with competitors. India's retail market is expected to cross 1.3 trillion USD by 2020 from the current market size of 500 billion USD. And by 2020, m-commerce will be the most preferred place for marketers, content creators and advertisers to reach out target audience. 


\section{Findings \& Conclusion}

In today's world, investors are showing more trust in Mutual Fund than any other financial product. Indian mutual fund industry has grown at a Compounded Annual Growth Rate (CAGR) of 15 per cent from FY09 to FY14. Today, there are 44 mutual fund companies operating various schemes tailored to meet the diversified needs of savers. The total assets under management crossed ' 12 trillion in February 2015. The young generation prefers SIP as their most preferred investment option which is provided by Mutual Funds. They do online banking, online shopping, online payments, e-ticketing and many others using the mobile internet. Future India is digital India where people mean fast, internet means $4 \mathrm{G}$ and business means online. Mobile commerce is undoubtedly a necessity for Future India.

\section{References}

Agarwal Anshu \& Bhatawal Pravin H, (2015), "M Commerce in India: Promise and Problems", International Journal of Research in Computer and Communication Technology, Vol 4, Issue 4.

Batra D. S \& Juneja, D. (2013), “M- Commerce in India: Emerging Issues”, International Journal of Advanced Research in IT and Engineering, Vol. 2(2), 54-65.

Gupta D. S \& Vyas M, (2014), "Benefits and Drawbacks of M-Commerce in India: A Review”, IJARCCE, 3(4), $6327,6328,6329$.

Mirzae, A., Asadollahi, A., \& Jahanshahi, A. A. (2014), "Mobile Commerce Beyond Electronic Commerce: Issue and Challenges", Asian Journal of Business and Management Sciences, Vol.1(2), 119-129.

Shintaro Okazaki (2005), "New Perspectives on M-Commerce Research", Journal of Electronic Commerce Research, VOL. 6, NO.3, 2005

S.Muthukumar\& N.Muthu (2015), "The Indian kaleidoscope: Emerging Trends in M-Commerce", International Journal of Advanced Research in Computer and Communication Engineering Vol. 4, January 2015

Tandon, R., Mandal , S., \& Saha, D. (2013), "M- Commerce- Issues and Challenges" Proceedings of the 10th Annual International Conference on High Performance Computing (HiPC), December 17-20, Hyderabad, India, 1-6.

Tripathy, Nalini Prava (2007), "Mutual Fund in India: A Financial Service in Capital Market", Finance India, Vol. X (1), pp. 85-91.

www.amfiindia.com

www.economictimes.com

www.forbes.com

www.moneycontrol.com 